\title{
The importance of algal cultures for the assessment of the eutrophication of the Oslofjord
}

\author{
O. M. SKulberg \\ Norwegian Institute for Water Research; Blindern, Norway
}

\begin{abstract}
KURZFASSUNG: Die Bedeutung von Algenkulturen für die Beurteilung der Eutrophierung des Oslofjordes. Im Rahmen hydrobiologischer Untersuchungen des Oslof jordes in der Zeit von 1962 bis 1965 wurden Versuche mit Algenkulturen durchgeführt, um die Eutrophierungsvorgänge zu charakterisieren. Als Testalgen dienten folgende Arten: Selenastrum capricornutum PrinTz, Chlorella ovalis BuTcher, Skeletonema costatum (Grev.) Cl. und Phaeodactylum tricornutum BoHLIN. Flußwasser, Fjordwasser, Abwasser und Mischungen von diesen Wassertypen wurden in biologischen Testverfahren untersucht, wobei die unter standardisierten Umweltbedingungen erzielte Biomasse der Testalgen für die Beurteilung der Wassergüte zugrunde gelegt wurde. Die Verwendung von Algenkulturen hat sich als eine geeignete methodische Ergänzung für Vorfluteruntersuchungen und für eine quantitative Bestimmung der Wassergüte erwiesen.
\end{abstract}

\section{INTRODUCTION}

During 1927 an important research work was published at the Biologische Anstalt Helgoland by Schreiber (1927). The paper „Die Reinkultur von marinem Phytoplankton und deren Bedeutung für die Erforschung der Produktionsfähigkeit des Meerwassers" documented that laboratory experiments with algal cultures support results contributing to the understanding of phytoplankton ecology.

Chemical analysis of water provides information on the quantity of plant nutrients present, but supplies no knowledge of their availability for algae. Studies with cultures of algae under controlled conditions give information on the "richness" and "quality" of the water for algal growth (JoHNSTON 1963).

Eutrophication is primarily caused by enrichment of water with plant nutrients, even though other environmental factors are involved. The influx of nutrients to the waters results in increased primary productivity by the stimulated development of vegetation. Eutrophication has become a serious water management concern of inland and coastal areas (VOLLENWEIDER 1968).

\section{GENERAL BACKGROUND}

During the period 1962-1965 a research project was carried out on the effect of pollution in the Oslofjord (BAALSRUd 1967b). An experimental investigation on the 
fertilization of the fjord water and the resulting growth of algae was included in the studies (Kotai \& SKulberg 1967).

The Oslofjord is a threshold fjord with pronounced brackish water stratification. The fjord consists of a number of deep basins, separated by shallow sills. Both the inner and the outer parts of the fjord have depths greater than $100 \mathrm{~m}$. The sill at Drøbak is only $19.5 \mathrm{~m}$ deep. A considerable amount of waste water is discharged into the Oslofjord from the city of Oslo (500,000 inhabitants) from industries and agriculture - and from urban areas surrounding the fjord. The process of eutrophication of the Oslofjord is a prime pollutional problem of practical concern (RuUD 1968).

When water samples from the outer and the inner part of the fjord are used in the laboratory for growth experiments with test algae, it is observed regularly that water samples from the inner fjord can support more growth of the test algae. The change of growth qualities from the outer to the inner parts of the fjord may be caused by the combined effects of the different contributing waters which are mixing and making up the fjord water. Important to consider is the sea water entering the fjord, the runoff water from the catchment areas, the bottom waters of the fjord and sewage and other polluting matter of urban origin. The relative importance of these different contributions for the eutrophication of the fjord may be evaluated by application of algal culture assays.

\section{PREVIOUS INVESTIGATIONS}

Cultivation of algae as a means of understanding environmental influence on populations has long traditions in Norway.

Cultures of marine phytoplankton were used to study responses to varying concentrations of inorganic nutrients (GRAN 1931). An investigation on the possibilities of using algal cultures for assessment of plant nutrients concluded that important results could be obtained (BRAARUD \& FøYN 1930). Experimental investigations on freshwater algae were indicative (STRøм 1933).

Diatoms, dinoflagellates and chrysophyceans are the major components of phytoplankton in the Oslofjord (BRAARUD 1945). Representatives of these taxonomic groups have mainly been employed for experimental investigations on algae in Norway.

Salinity and temperature are important environmental factors for the distribution of species. Algal culture experiments have resulted in knowledge which contributes in explaining the occurrence of certain species in nature (BRAARUD 1951). Experimental studies on the dinoflagellate Peridinium triquetrum established the requirements of the species with respect to factors such as salinity, light and temperature (BRAARUD \& PAPpas 1951). The growth response to sewage additions was also investigated during this study.

Culture experiments with species of Ceratium (NoRdir 1953) concluded that the mass occurrence of ceratia in the Oslofjord may partly be ascribed to favourable temperature and salinity conditions.

The use of algal cultures in assays concerning the effect of pollution on eutrophication have shown that such procedures are fruitful supplements to field investigations 
(SKULBERg 1964). The experience gained from the laboratory research emphasize that the experimental use of algae in ecological studies should be extended (BRAARUD 1961).

\section{PROCEDURES AND METHODS}

The algal assay procedure used during the investigation has been described previously (Skulberg 1967). 'The test algae selected for the investigation are listed in Table 1. Unialgal clone cultures were used for the assays. Yield was determined, defined as the maximum quantity of algal cells obtained in the specific set of growth conditions. The dichromate oxygen demand of the cells of the test algae are given in the table.

\section{Table 1}

The test algae and their chemical oxygen demands

$\left(\mathrm{K}_{2} \mathrm{Cr}_{2} \mathrm{O}_{7}\right.$-method, American Public Health Association 1965, 510-514)

\begin{tabular}{|cc|}
\hline Species & $\begin{array}{c}\text { Dichromate value } \\
\mathrm{n} \cdot 10^{-8} \mathrm{mg} \mathrm{O} / \text { cell }\end{array}$ \\
\hline Selenastrum capricornutum Printz & 4.5 \\
Chlorella ovalis BuTcher & 5.4 \\
Skeletonema costatum (GREviLLE) ClEVE & 8.0 \\
Phaeodactylum tricornutum BoiLIN & 2.6 \\
\hline
\end{tabular}

All of the quantitative culture experiments were made in glass flasks (Jenaer Geräteglass 20; volume 2 litres) containing 1 litre culture solution. Cultivation was performed in a constant temperature room at $20^{\circ} \mathrm{C}$. Illumination was provided by fluorescent lamps (Philips TL $40 \mathrm{~W} / 32$ ) which gave about 6000 lux at rack level, and exposed the algae to vertical light. A mechanical arrangement kept the cultures in shaking movements in order to prevent settling and to give an adequate supply of $\mathrm{CO}_{2}$.

When samples of inland waters and fjord water were used either directly, in combination, or in enrichment experiments as media for growth of the test algae, preceding filtration was carried out with glass fibre papers (Whatman, GF/A). For experiments on growth of the test algae in media containing sewage, filtered sewage was used without further treatment.

Growth experiments lasted approximately 14 days. The increase in cell numbers in the cultures was determined. Cell counts were made with a celloscope (A/B Lars Ljungberg \& Co., Celloscope 202), a haemocytometer counting chamber (Bürker), or the inverted microscope technique. During the period of experiment the exponential phase, the phase of declining relative growth, and the stationary phase of growth were observed.

\section{ALGAL GROWTH ASSAYS OF TRIBUTARIES AND SEWAGE}

\section{Runoff water}

The inland waters of the catchment area of the inner Oslofjord are classified into four categories with regard to their water types. They vary from the dis- 
tinct oligotrophic-dystrophic type to the extreme eutrophic type. Table 2 presents geographical and chenical data of four lakes selected as typical for the watercourses forming tributaries to the fjord.

\section{Table 2}

Geographical and chemical data of the Norwegian lakes Maridalsvatn, Gjersjøen, Ārungen and Aurevatn. (Data from the Norwegian Institute for Water Research)

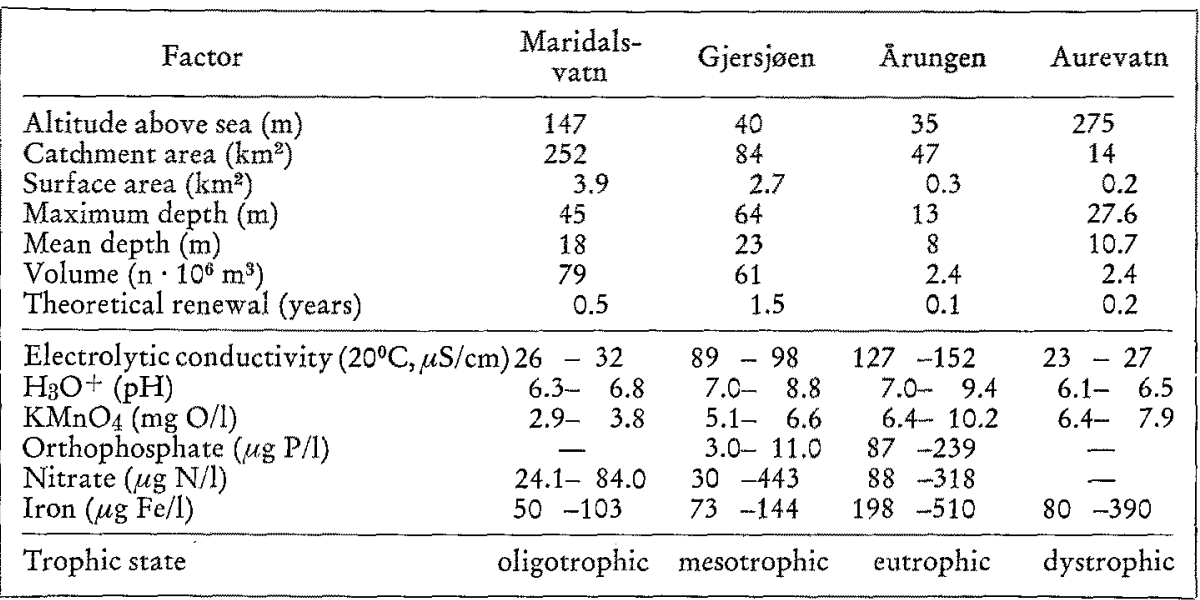

The algal vegetation of these inland waters is rich in species and grows fairly profusely. The varied geological conditions of the catchment area are significant causes for this phenomenon (PRINTZ 1914); in addition, the utilization of land for agricultural purposes and human settlement has led to an enrichment of water stimulating algal growth (SKulBerg 1968).

Lakes in watercourses are efficient traps of fertility. The application of algal culture assays has resulted in qualitative and quantitative information on this fact. From

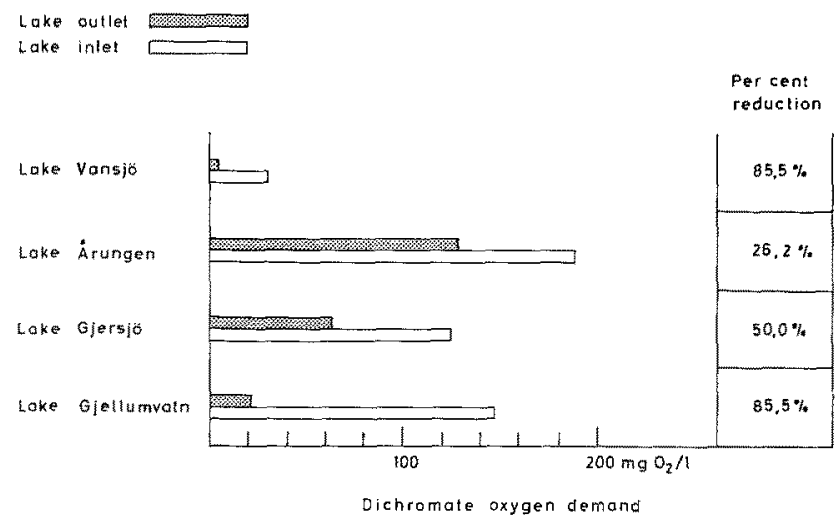

Fig. 1: Lakes as traps of fertility. Results of algal growth assays in water samples from the inlets and outlets of some Norwegian lakes 
the results plotted in Figure 1 it follows that the lakes caused pronounced alterations of growth qualities of the water flowing through them.

The lake effect is altered during lake succession from oligotrophy to eutrophy. Important factors to consider in this connection are lake morphology, water renewal,

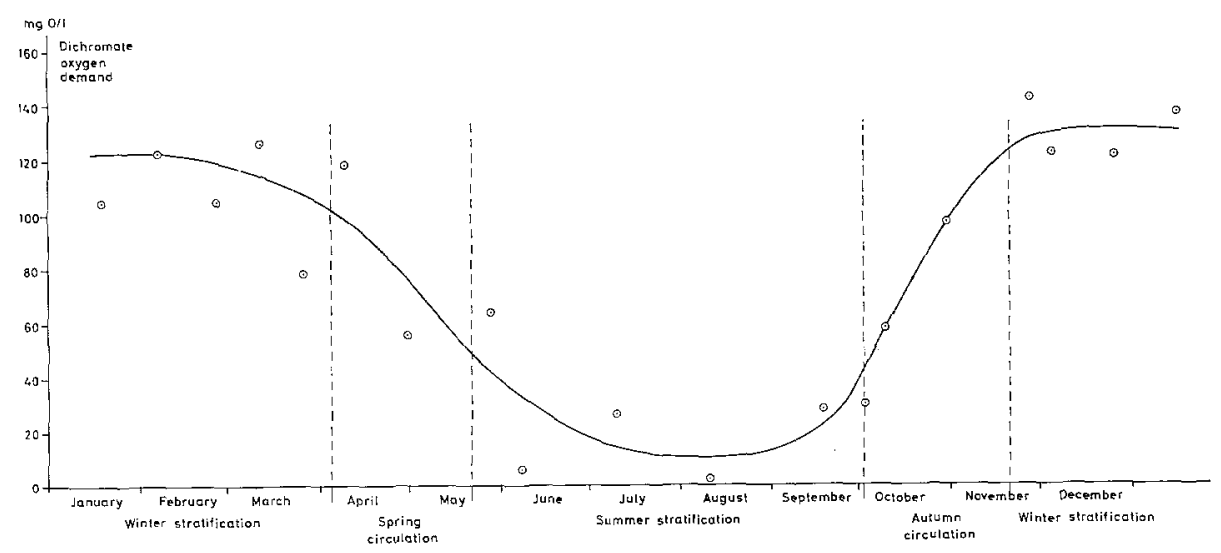

Fig. 2: Seasonal variation of algal growth assay results. Lake Årungen; surface water

nature of catchment area and bioactivity in the lake. Seasonal changes are to be expected, due to depletion of the plant nutrients during the period of vegetation. Results of algal growth assays illustrating these events in Lake Årungen are presented in Figure 2. The results of the algal growth assays varied inversely with the development of vegetation in the lake.

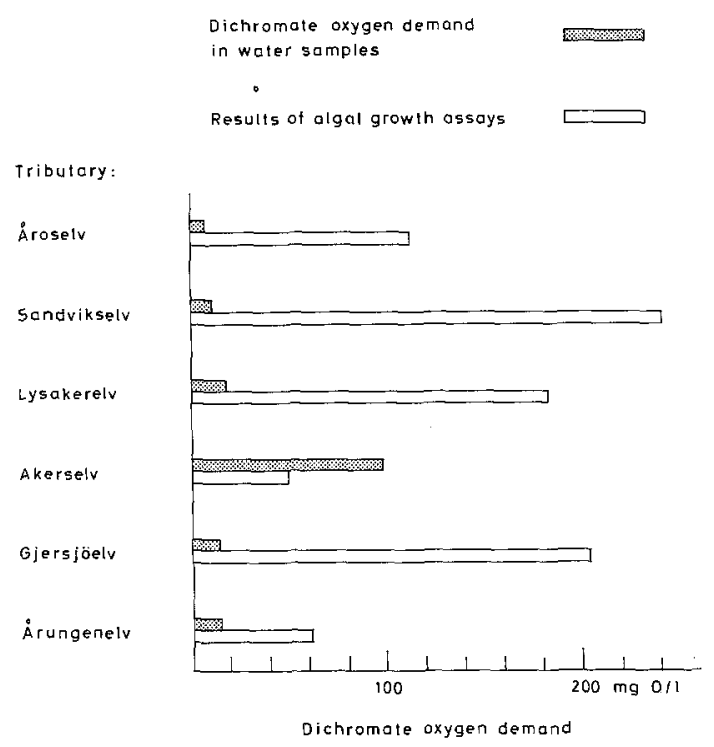

Fig. 3: Results of algal growth assays. Water samples from tributaries of the inner Oslo Fjord 
The lakes in the watercourses of the inner Oslofjord are so situated that the lake effect in most cases is of little significance to protect the fjord. This fact is reflected in the results of algal growth assays of water samples from the tributaries. Water samples were collected close to the mouth of the rivers, but above the influence of salt water. An example of results obtained for the six important rivers of the inner Oslofjord on February 18th, 1964 are plotted in Figure 3.

Due to contents of poisonous substances for algae in the water of the River Akerselv complications arose. The other assay cultures developed satisfactorily. All the rivers carried water rich in nutrients available for algal growth. These nutrients rendered possible a secondary production of organic substance which exceeded the primary contents of organic substance present in the river water.

\section{The effect of sewage on algal growth}

The chemical composition of sewage and the growth qualities of sewage for algae have been extensively investigated (Allen 1955, Oswald et al. 1959, Burlew 1953). Table 3 contains information on the contents in human excretions of elements essential for the growth of algae. The concentrations of these elements in sewage are calculated and compared with the actual concentrations in the standard algal culture medium used. The concentration in sewage of the same elements determined by chemical analysis is included.

Table 3

Composition of human excretions, algal nutrient solution and raw sewage

\begin{tabular}{|c|c|c|c|c|}
\hline Elements & $\begin{array}{l}\text { Excretions } \\
\text { (mg/person } \\
\text { and day*) }\end{array}$ & $\begin{array}{c}\text { Excretions } \\
(\mathrm{mg} / 1 \text { sewage }\end{array}$ & $\begin{array}{l}\text { Nutrient solution } \\
\quad(\mathrm{mg} / 1 * \% * \%)\end{array}$ & $\begin{array}{l}\text { Raw sewage } \\
(\mathrm{mg} / \mathrm{l}+\ldots \ldots+\%)\end{array}$ \\
\hline $\mathrm{Na}$ & 4735 & 18.9 & 153.3 & - \\
\hline $\mathrm{Ca}$ & 840 & 3.3 & 10 & $16.2-23.1$ \\
\hline $\mathrm{K}$ & 3210 & 12.8 & 13.9 & $7.2-11.0$ \\
\hline $\mathrm{Mg}$ & 303 & 1.2 & 2.5 & $3.5-4.4$ \\
\hline $\mathrm{Fe}$ & 0.64 & 0.0025 & 0.6 & $1.3-2.9$ \\
\hline $\mathrm{N}$ & 16300 & 65.2 & 83.9 & $17.4-31.9$ \\
\hline $\mathrm{P}$ & 1610 & 6.4 & 5. & $3.7-6.9$ \\
\hline $\mathrm{S}$ & 1750 & 7.0 & 3.2 & $3.5-4.5$ \\
\hline \multicolumn{5}{|c|}{$\begin{array}{l}\text { Data from Scientific Tables (Documenta Geigy 1962, pp. 526, } 533 \text { and 534). } \\
\text { Calculated; volume of water } 250 \text { I per person and day. } \\
\text { After SkulBERG (1967, p. 115). } \\
\text { Chemical analysis of raw sewage from Kjellerholen, Romerike (Norwegian Institute } \\
\text { for Water Research). }\end{array}$} \\
\hline
\end{tabular}

Two important facts asserted from the data in Table 3 will be mentioned. First, sewage which is chiefly composed of human excretions contains all the essential elements for algal growth. Second, the elements in sewage of this nature are present almost in the same proportional relationship as in an optimal algal culture medium. 
The algae used during the investigation, Selenastrum capricornutum, Chlorella ovalis, Skeletonema costatum and Phaeodactylum tricornutum, developed well in mixtures of sewage with recipient water. The growth was stimulated by increasing additions of sewage. When the concentration of sewage exceeded 10 per cent, the growth of Skeletonema costatum was impeded. The other test algae developed well in undiluted sewage.

Quantitative growth experiments were conducted on recipient water with sewage added. The aim was to evaluate the secondary load of organic substances produced by growth of algae compared to the primary load due to organic substances contained in the sewage.

The test algae Selenastrum capricornutum, Chlorella ovalis and Phaeodactylum tricornutum were used. For this purpose samples of raw sewage from the Skarpsno Sewage Treatment Plant, Oslo, were mixed with water samples from the Lake Maridalsvatn and Årungen, and from the Oslofjord. The results of algal growth experiments using 10 percent sewage addition are given in Figure 4.

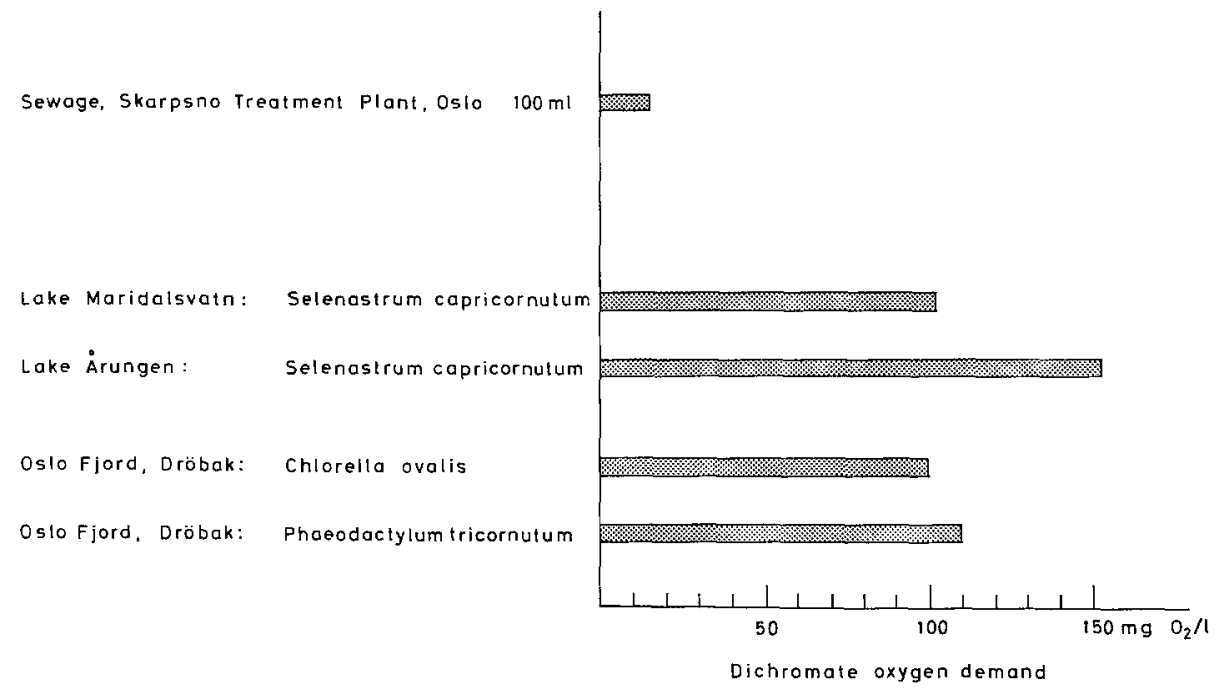

Fig. 4: The dichromate oxygen demand caused by $100 \mathrm{ml}$ sewage added to water samples from Lake Maridalsyatn, Lake Ârungen and Oslo Fjord compared with the dichromate oxygen demand resulting from algal growth in the same water mixtures

Summing up the results of the quantitative experiments using diluted sewage as nutrient solution, it stands out that the nutrients in sewage gives good growth possibilities for algae. The secondary load of organic substances produced by the algal growth, moderately expressed and the existent conditions assumed, constitute 5 to 10 times the primary load of organic substances caused by sewage in the same water mixture (SKULBERg 1967). This result has since been confirmed on a theoretical basis during a Swedish investigation (AHL et al. 1967). 


\section{EFFECTS OF POLLUTION ON THE FERTILITY OF FJORD WATER}

Phytoplankton is responsible for the major part of the production in the inner Oslofjord. A great number of phytoplankton samples have been collected and examined during the investigation 1962 to 1965 (BraArud \& NygaARd 1967). The occurrence of planktonic algae varies between different areas of the fjord and at different times. A marked influence of the fertilizing effect of pollution was demonstrated by the phytoplankton survey.

During the late part of the vegetation period the algae are prolific in the Oslofjord. Diatoms and dinoflagellates are dominating in the phytoplankton, and Skeletonema costatum, Ceratium furca, Gymnodinium sp. and Prorocentrum micans are among the species of quantitative importance.

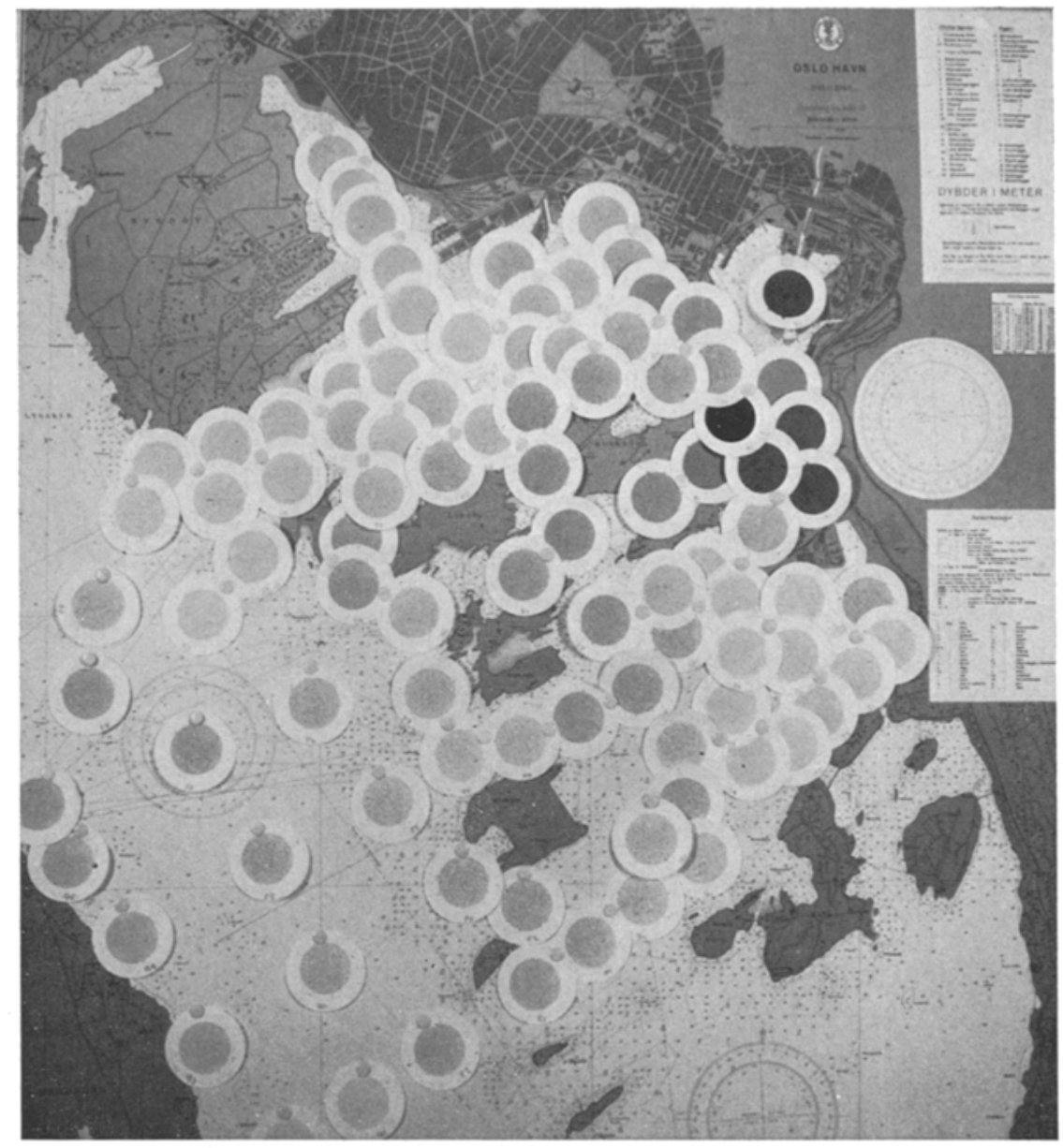

Fig. 5: Water samples were collected from 96 stations on October 12, 1965 and filtered through glass fibre papers. Several of the filter papers are mounted on the respective collection stations 
Water samples of surface waters were collected from 96 stations on October 12th, 1965 and filtered through glass fibre papers. Figure 5 shows several of the filter papers mounted in their respective positions on the map. Microscopical examination disclosed that the seston contained organisms, detritus and other particles. The plankton component, however, was of major importance quantitatively.

The population of plankton was concentrated in the inner island area, especially in proximity to sewage discharges. In the outer island areas there was a decrease in the concentration of plankton.

The water samples after filtration were used for quantitative growth tests with

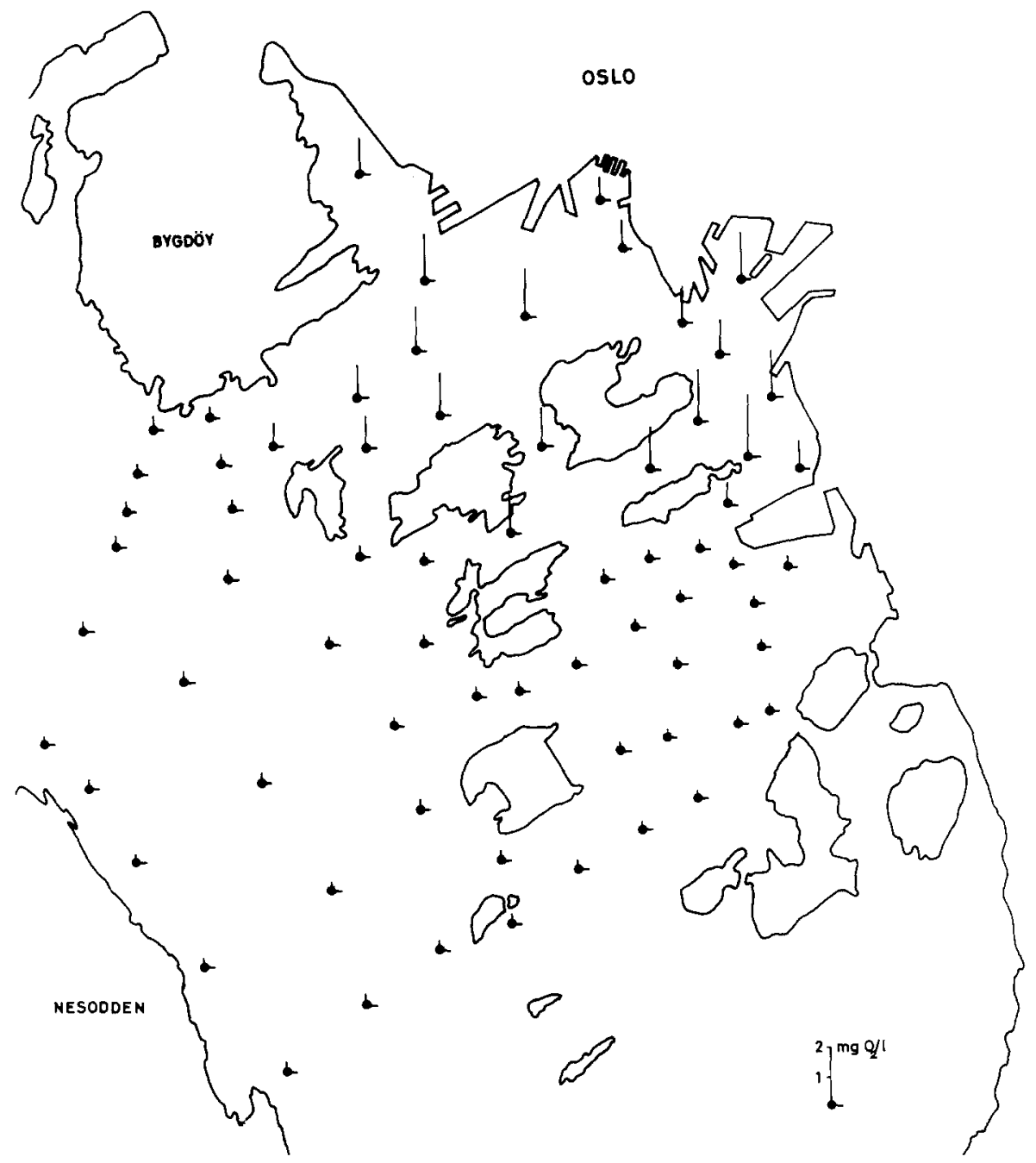

Fig. 6: Results of algal growth assay with Skeletonema costatum. Surface waters (1 m depth) October 12, 1965 
Skeletonema costatum. The results of the algal assay are graphically expressed in Figure 6. Significant growth of the test alga was obtained in the water samples collected in the inner island area. Available plant nutrients were not present in sufficient amounts to obtain definite growth of the test alga in the water samples from the stations of the outer island area.

The changing growth qualities of the waters in longitudinal direction of the fjord were surveyed. An example of results will be given. On November $18 \mathrm{th}, 1965$ water samples were collected from 1 metre depth on five stations distributed on the $100 \mathrm{~km}$ distance from Oslo harbour - Frrder. The filtered water samples were used for quantitative growth tests with Phaeodactylum tricornutum and Chlorella ovalis. The results, presented in Figure 7, describe the regional variation of fertility of the waters.

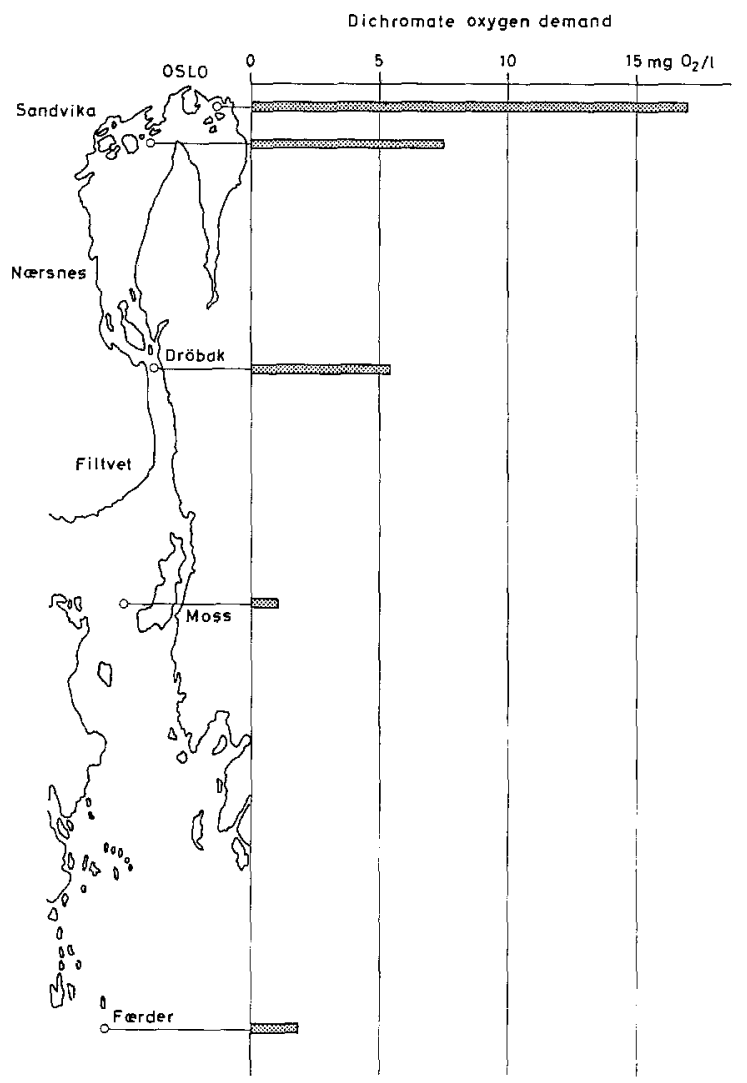

Fig. 7: Regional variations of algal growth assay results, surface water $(1 \mathrm{~m}$ depth) November 18,1965

Enrichment experiments with essential nutrients were carried out during the investigation in order to determine the elements present in limiting amounts.

Iron-containing humic compounds drained from land, may be of importance for the rich growth of diatoms and other algae in the fjord water. Experiments with 
Skeletonema costatum and water from the Oslofjord demonstrated that substances of this nature were decisive for the growth which could be obtained. The results have drawn attention to the natural runoff water quality as an important factor for the phytoplankton development.

From the results of adding $\mathrm{PO}_{4}-\mathrm{P}$ and $\mathrm{NO}_{3}-\mathrm{N}$ to the waters it was concluded that the availability of nitrate as well as of orthophosphate was important for the total

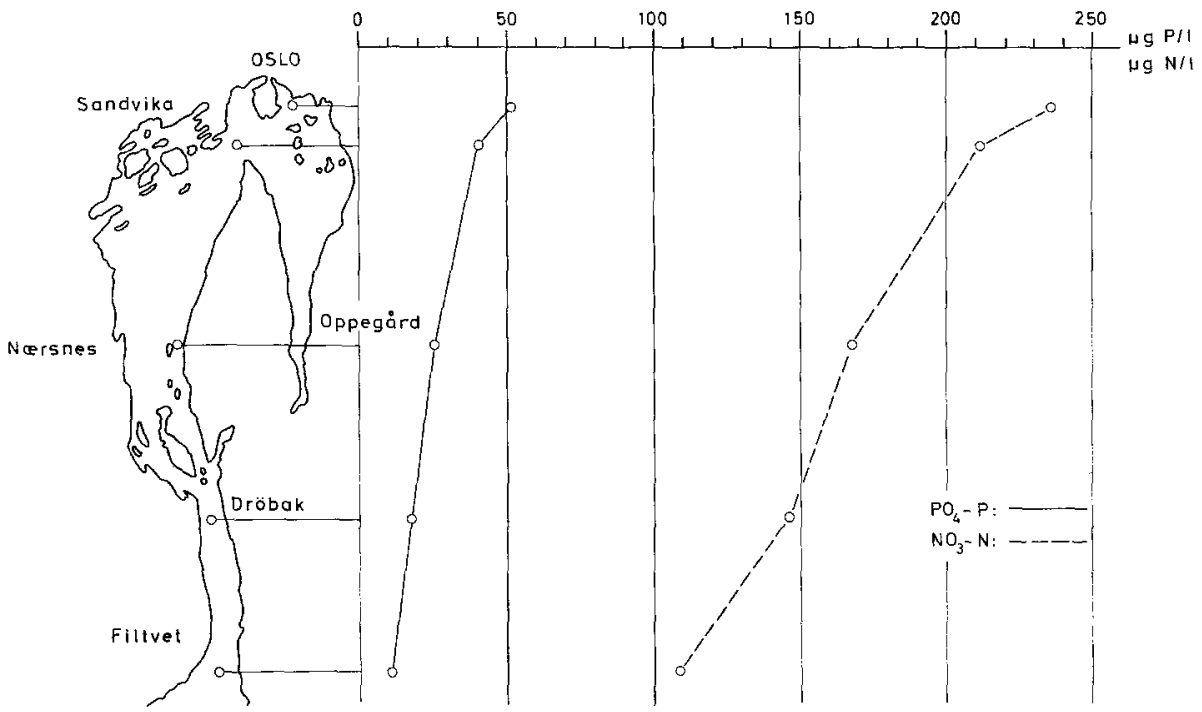

Fig. 8: Regional changes in $\mathrm{NO}_{3}-\mathrm{N}$ and $\mathrm{PO}_{4}-\mathrm{P}$ concentrations of surface waters (1-8 $\mathrm{m}$ depth) during winter

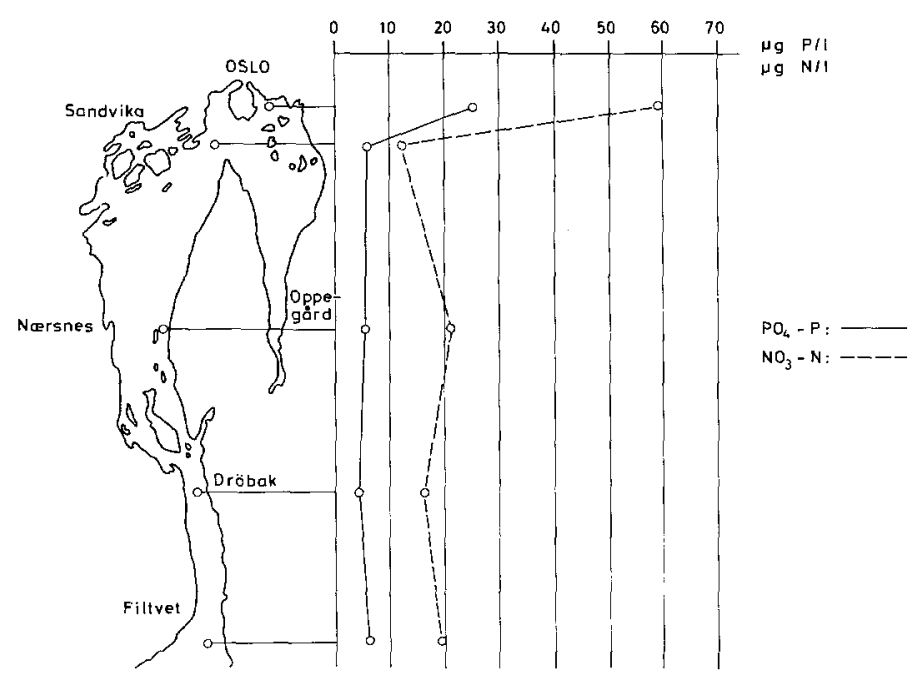

Fig. 9: Regional changes in $\mathrm{NO}_{3}-\mathrm{N}$ and $\mathrm{PO}_{4}-\mathrm{P}$ concentrations of surface waters (1-8 $\mathrm{m}$ depth) during the vegetation period 
yield of algae. It was not possible to ascribe the main fertilizing effect to any one of these components.

The marked changes in eutrophic direction, manifested by the algal assay results of the fjord waters with increasing yields obtained towards the inner areas of the fjord, were in agreement with the results of the chemical investigation (FoYN 1967).

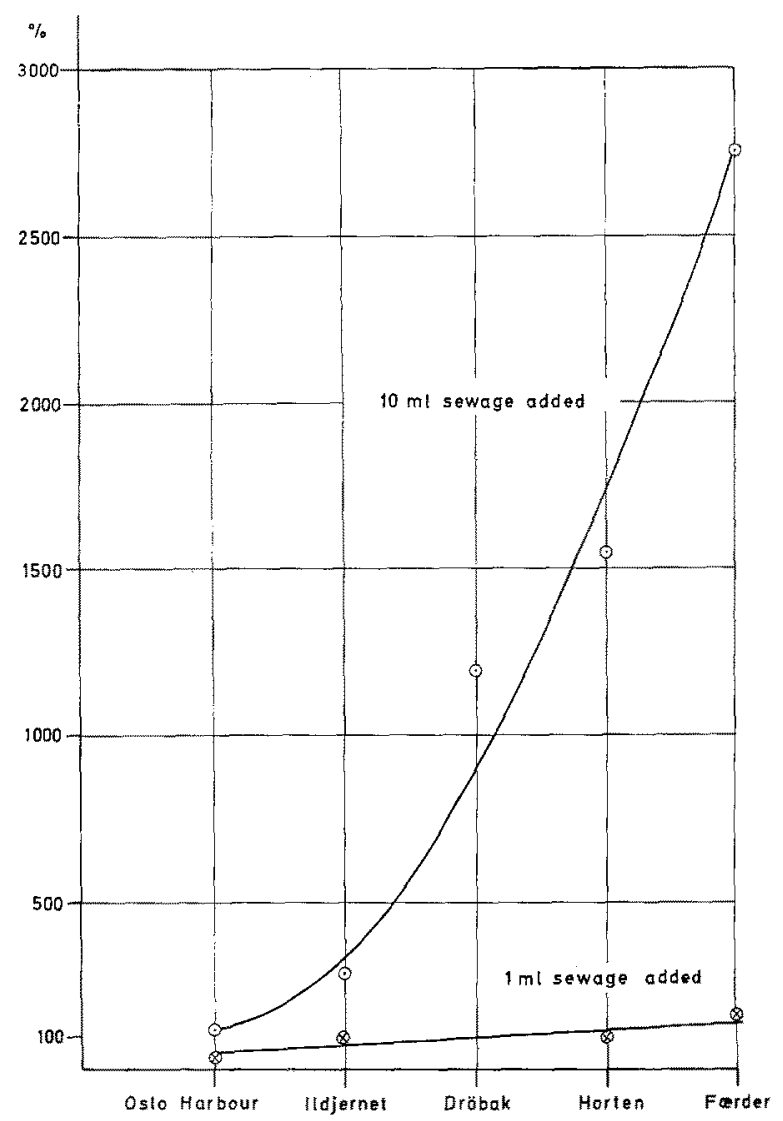

Fig. 10: Increase in algal growth caused by addition of sewage to water samples from the Oslo Fjord. Growth of the test algae (Phaeodactylum tricornutum and Chlorella ovalis) in water samples with no addition of sewage is designated $100 \%$

Chemical data describing the variations in concentrations of $\mathrm{NO}_{3}-\mathrm{N}$ and $\mathrm{PO}_{4}-\mathrm{P}$ in surface waters (1-8 $\mathrm{m}$ depth) at different stations along the Oslofjord are diagrammatized in Figures 8 and 9. The data represent determinations on filtered water samples as calculated from the average of values obtained in 1, 4 and $8 \mathrm{~m}$ depth water samples (1962-1965). The diagrams present the winter period (November-March) and the vegetation period (April-October). The regional and seasonal fluctuations in the concentrations of these important plant nutrients are illustrated. 
The algal assay results made possible a discussion of the chemical data. During the winter period physical factors were limiting the primary production in the fjord. High levels of $\mathrm{PO}_{4}-\mathrm{P}$ and $\mathrm{NO}_{3}-\mathrm{N}$ were observed in the surface layers. During the vegetation period the development of plankton algae caused an effective reduction of the concentrations of plant nutrients in the water masses. Available orthophosphate for algal growth was present in the surface layers during the whole vegetation period. This indicates that under the prevailing hydrographical conditions it is not orthophosphate which limits the production of algae. The ability of the algae to concentrate orthophosphate in their cells has also to be considered in this connection (LEwIN 1962). The reduction of $\mathrm{NO}_{3}-\mathrm{N}$ compared with the reduction of $\mathrm{PO}_{4}-\mathrm{P}$ in the productive layers during the vegetation period suggests another source of $\mathrm{PO}_{4}-\mathrm{P}$ than sewage to these layers. Obviously, the accumulation of phosphate in the bottom water layers (STRøM 1936), the estuarine circulation (REDFIELD et al. 1963) and drainage water from the catchment area are factors to be evaluated.

The chemical composition of sewage (Table 3) implies that over a wide range of concentrations there will be a direct proportionality between amount of sewage and the response of algal growth in recipient water. However, the results of algal assays have demonstrated that the nature of the recipient water may be as important for the effect of pollution as the amount and composition of the sewage itself (BAALSRUD 1967a). Results of experiments with fjord water and sewage additions are presented in Figure 10. Water samples from five stations were used for algal assays with Phaeodactylum tricornutum and Chlorella ovalis. Different increase in algal growth was obtained.

\section{CONCLUSIONS}

By application of algal assays information was obtained about the amounts and availability of plant nutrients for algal growth. The results gave valuable supplements to the chemical and physical methods used in the study of the pollutional situation.

Results of algal assays on tributary waters demonstrated their eutrophic nature. Plant nutrients from the catchment areas are transported to the fjord with pronounced fertilizing effects on receiving waters.

The content of plant nutrients in sewage render possible a secondary load of organic substances in the recipient water by algal growth which amounts to 5 to 10 times the primary load of organic substances contained in sewage.

Results of algal assays of Oslofjord water with addition of sewage indicated that water of the inner part of the fjord was in a condition where a significant increase in sewage load gave a relatively small increase in algal growth. Conversely, a small addition of sewage to water samples from the outer Oslofjord gave a fairly high increase in growth response.

Enrichment experiments with essential nutrients indicated that the supply of compounds of nitrogen, phosphorus and iron was important for the resulting yield of algae. It was not possible to ascribe the main fertilizing effect to any single one of the nutrients. 


\section{SUMMARY}

1. Assay experiments with unialgal cultures have been carried out in connection with an investigation of the Oslofjord 1962 to 1965. The test algae included the following species: Selenastrum capricornutum PRINTz, Chlorella ovalis BUTCHER, Skeletonema costatum (GREV.) CL. and Phaeodactylum tricornutum BoHLIN.

2. In the Oslofjord three different types of water are mixed: sea water from the open sea, fresh water from the tributaries, and polluted discharges. The algal growth assays have given information on the amounts and availability of plant nutrients in the water. The quality of the water for algal growth was determined.

3. The results indicated that the water of the inner part of the fjord was in a condition where a significant increase in sewage load gave a relatively small increase in algal growth. Conversely, it was found that for water samples from the outer Oslofjord, a small addition of sewage would give relatively high increase in growth.

4. Enrichment experiments with essential nutrients showed that the supply of compounds of nitrogen, phosphorus and iron was important for the resulting yield of algae. It was not possible to ascribe the main fertilizing effect to any single one of the components.

Acknowledgements. The study has been performed at the Norwegian Institute for Water Research. Grateful appreciation is expressed to Mr. K. BaAlsRud, Director of the Institute. The author acknowledges the assistance of J. KoT'AI who was in charge of the laboratory work and helped during all phases of the investigation. Thanks are due to the several collaborators who assisted in the field work.

\section{LITERATURE CITED}

Ahl, T., Karlgren, L., Olsson, E. \& Tullander, V., 1967. Hushållsavloppsvatnet - en undersökning av sammansättning och egenskaper. Vatten 23 (3), 178-204.

Alden, M. B., 1955. General features of algal growth in sewage oxidation ponds. Publs St. Wat. Pollut. Control Bd 13,1-48.

American Public Health Association, 1965. Standard methods for the examination of water and wastewater, $12 \mathrm{th}$ ed. New York.

BaAlsrud, K., 1967a. Polluting material and polluting effect. Wat. Pollut. Control, Lond. 66, 97-106.

- 1967b. Oslofjorden og dens forurensningsproblemer. I. Undersøkelsen 1962-1965. Samlerapport. Norwegian Institute for Water Research, Oslo.

BraArud, T. \& Føyn, E., 1930. Beiträge zur Kenntnis des Stoffwechsels im Meere. Avh. norske VidenskAkad. Oslo (Mat.-nat. K1.) 14.

- 1945. A phytoplankton survey of the polluted waters of inner Oslo Fjord. Hvalråd. Skr. 28, 1-142.

- 1951. Salinity as an ecological factor in marine phytoplankton. Physiologia Pl. 4, 28-34.

- \& PAPPas, I., 1951. Experimental studies on the dinoflagellate Peridinium triquetrum (Ehrb.) Lebour. Avh. norske VidenskAkad. Oslo (Mat.-nat. Kl.) 14, 1-23.

- 1961. Cultivation of marine organisms as a means of understanding environmental influences on populations. In: Oceanography. Invited lectures presented at the International Oceanographic Congress, New York 1959. Ed. by M. Sears. (Publs Am. Ass. Advmt Sci. 67, 271-298. 
- \& Nygaard, I., 1967. Fytoplankton. In: Oslofjorden og dens forurensningsproblemer. I. Undersøkelsen 1962-1965. Norwegian Institute for Water Research, Oslo, 4, 1-171.

Burlew, J. S., 1953. Algal culture from laboratory to pilot plant. Publs Carnegie Instn 600, $1-357$.

Documenta Geigy, 1962. Scientific tables. 6th ed., Basel.

FøYn, E., 1967. Vurdering av næringssaltenes kjemi. In: Oslofjorden og dens forurensningsproblemer. I. Undersøkelsen 1962-1965. Norwegian Institute for Water Research, Oslo, 8, $1-18$.

Gran, H. H., 1931. On the conditions for the production of plankton in the sea. Rapp. P.-v. Réun. Cons. perm. int. Explor. Mer 75, 37-46.

Johnston, R., 1963. Sea water, the natural medium of phytoplankton. I. General Features. J. mar. biol. Ass. U.K. 43, 427-456.

Kotai, J. \& Skulberg, O., 1967. En eksperimentell undersøkelse av fjordvannets gjødslingspåvirkning og den resulterende algevekst. In: Oslofjorden og dens forurensningsproblemer. I. Undersøkelsen 1962-1965. Norwegian Institute for Water Research, Oslo, 10, 1-78.

LEWIN, R. A., 1962. Physiology and biochemistry of algae. Academic Press, New York, 929 pp.

NordLI, E., 1953. Salinity and temperature as controlling factors for distribution and mass occurrence of Ceratia. Blyttia 11, 16-18.

Oswald, W., Golueke, C. \& GotaAs, H., 1959. Experiments on algal culture in a field-scale oxidation pond. Sanitary Engineering Research Laboratory, University of California, Berkeley. (I.E.R. 44, 1-42. Issue No 10.)

PrinTZ, H., 1914. Kristianiatraktens protococcoideer, Skr.VidenskSelsk. Christiania (Mat.-nat. Kl.) 6, 1-123.

RedField, A. C., Ketchum, B. H. \& Richards, F. A., 1963. The influence of organisms on the composition of sea-water. In: The sea. Ideas and observations on progress in the study of the seas. Ed. by M. N. Hill. Wiley, New York, 2, 26-77.

Ruud, J. T., 1968. Introduction to the studies of pollution in the Oslof jord. Helgoländer wiss. Meeresunters. 17, 455-461.

SCHREIBER, E., 1927. Die Reinkultur von marinen Phytoplankton und deren Bedeutung für die Erforschung der Produktionsfähigkeit des Meerwassers. Wiss. Meeresunters. Abt. Helgoland $16(10), 1-23$.

SkUlberg, O., 1964. Algal problems related to the eutrophication of European water supplies. In: Algae and man. Ed. by D. F. Jackson. Plenum press, New York, 262-299.

- 1967. Algal cultures as a means to assess the fertilizing influence of pollution. Water Pollution Control Federation, Washington, D. C., 113-127.

- 1968. Studies on eutrophication of some Norwegian inland waters. Mitt. int. Verein. theor. angew. Limnol. 14, 187-200.

Strøм, K. M., 1933. Nutrition of algae. Arch. Hydrobiol. 25, 38-47.

- 1936. Land-locked waters. Skr. norske Vidensk-Akad. (Mat.-nat. Kl.) 7, 1-86.

VOLLENWEIDER, R. A., 1968. Scientific fundamentals of the eutrophication of lakes and flowing waters, with particular reference to nitrogen and phosphorus as factors in eutrophication. Organisation for economic co-operation and development, Paris, DAS/CSI/68. 27, 59.

Author's address: O. M. Skulberg

Norsk institutt for vannforskning

Gaustadalléen 25

Blindern, Oslo 3, Norway 